\section{The role of haploinsufficiency of RPS14 and p53 activation in the molecular pathogenesis of the $5 q$ - syndrome}

\author{
Jacqueline Boultwood \\ LLR Molecular Haematology Unit, \\ NDCLS, John Radcliffe Hospital, \\ Oxford, UK
}

\section{Abstract}

In recent years we have gained great insight into the molecular pathogenesis of the $5 \mathrm{q}$ - syndrome, a distinct subtype of myelodysplasia. The demonstration of haploinsufficiency of the ribosomal gene RPS14 (mapping to the commonly deleted region) and the finding that this is the cause of the erythroid defect in the $5 \mathrm{q}$ syndrome represent major advances. A mouse model of the human $5 \mathrm{q}$ - syndrome generated by large-scale deletion of the Cd74-Nid67 interval (containing RPS14) further supports a critical role for RPS14 haploinsufficiency. It is widely accepted that ribosomal deficiency results in p53 activation and defective erythropoiesis and the crossing of the ' $5 \mathrm{q}$ - mice' with p53 deficient mice ameliorated the erythroid progenitor defect. Emerging data suggests that the p53 activation observed in the mouse model may also apply to the human $5 q$ - syndrome.

\section{The 5q- syndrome}

The $5 q$ - syndrome was first described in 1974 by Van den Berghe who reported the consistent association of the deletion of the long arm of chromosome $5[\operatorname{del}(5 q)]$ with the following hematological features: macrocytosis, anemia, normal or high platelet count and hypolobulated megakaryocytes in the bone marrow. ${ }^{1}$ From the earliest studies a good prognosis and a marked female preponderance have also been reported. ${ }^{2,3}$ The $5 q$ - syndrome is widely considered the most distinct of all the myelodysplastic syndromes and, importantly, this MDS subtype is characterized by a clear genotype-phenotype relationship which is not observed in other MDS and acute myeloid leukemia (AML) characterized by chromosomal deletions. The $5 \mathrm{q}$ - syndrome is now recognized as a distinct clinical entity according to the WHO classification and is defined by a medullary blast count of $<5 \%$ and the presence of the $\operatorname{del}(5 q)$ as the sole karyotypic abnormality. ${ }^{4}$
Mapping the commonly deleted region and identifying candidate genes

The identification of significant genes associated with chromosome deletions in human leukaemia has proven challenging. The $\operatorname{del}(5 q)$ in the $5 q$ - syndrome is considered to mark the location for a gene(s) the loss of which may affect important processes such as growth control and normal hematopoiesis. ${ }^{2}$ The basis for research on deletions such as the $\operatorname{del}(5 q)$ in the $5 q-$ syndrome is well known. The first step is to characterize the deletions and to identify the commonly deleted region (CDR) i.e. the region of deletion shared by all patients as this localises the gene(s) for further study. Our group in 0xford identified the CDR of the $5 q$ - syndrome ${ }^{5,6}$ and have since narrowed the CDR to the approximately $1.5 \mathrm{Mb}$ interval at 5 q32 flanked by D5S413 and the GLRA1 gene. ${ }^{7}$ We subsequently generated a transcription map of the CDR and noted several promising candidate genes map within this region, including the tumour suppressor gene SPARC, and RPS14, a component of the $40 \mathrm{~S}$ ribosomal subunit.7,8 The next step in our research was the sequencing of all the 40 genes that map within the CDR in a group of patients with the $5 q$ - syndrome. ${ }^{8}$ The gene sequencing is critical to understanding the pathogenesis of the $5 \mathrm{q}$ syndrome; if Knudsen's two hit model ${ }^{9}$ applied to this disorder there would be loss of one allele of a gene and a mutation of the remaining copy of the same gene. We have sequenced al the genes in the CDR and no mutations have been identified. ${ }^{8}$ This is a key step in determining the molecular basis of the $5 q$ - syndrome since it brings forward the consideration of haploinsufficiency (a gene dosage effect resulting from the loss of one allele of a gene) ${ }^{10}$ as the basis of the $5 q$ - syndrome. There has been growing recognition of haploinsufficiency as a cancer model over the last decade and we believe that this is the correct model for the $5 q$ - syndrome.

\section{Haploinsufficiency of RPS14 causes the erythroid defect in the 5q- syndrome}

We have recently demonstrated haploinsufficiency of the ribosomal gene RPS14 in the CD34+ cells of patients with the 5q- syndrome. ${ }^{8}$ The genes in the $5 \mathrm{q}$ - syndrome CDR were studied by an RNA-mediated interference (RNAi)- based approach by Ebert et al. and it was shown that partial loss of function (hapolinsufficiency) of RPS14 in normal hematopoietic stem cells resulted in a block in erythroid differentiation with relative preservation of megakaryocyte differentiation ${ }^{11}$ closely mirroring the defects observed in the $5 q$ - syndrome. Moreover, forced expression of
Correspondence: Jacqueline Boultwood, LLR Molecular Haematology Unit, NDCLS, John Radcliffe Hospital, Oxford, UK.

E-mail: jacqueline.boultwood@ndcls.ox.ac.uk

Key words: 5q- syndrome, p53 activation, rps14 haploinsufficiency.

Received for publication: 4 May 2011. Accepted for publication: 4 June 2011.

This work is licensed under a Creative Commons Attribution NonCommercial 3.0 License (CC BYNC 3.0).

(C) Copyright J. Boultwood, 2011

Licensee PAGEPress, Italy

Pediatric Reports 2011; 3(s2):e10

doi:10.4081/pr.2011.s2.e10

an RPS14 cDNA in primary bone marrow cells from patients with the $5 \mathrm{q}$ - syndrome rescued the phenotype, strongly suggesting that RPS14 is a $5 \mathrm{q}$ - syndrome gene. 11

That reduced expression of a ribosomal protein plays a key role in the development of a myeloid malignancy may initially seem surprising. However, Diamond-Blackfan anaemia (DBA), a congenital hypoplastic anemia, is also caused by haploinsufficiency of certain ribosomal proteins. The phenotype of DBA is remarkably similar to the $5 q^{-}$syndrome since patients have a severe anaemia, macrocytosis, relative preservation of the platelet and neutrophil counts, erythroid hypoplasia in the bone marrow and an increased risk of leukaemia. ${ }^{12}$ Mutations in RPS19, required for the maturation of $40 \mathrm{~S}$ ribosomal subunits, are found in approximately $25 \%$ of DBA patients and lead to haploinsufficiency of RPS19.13,14 Deficiency of RPS19 has been shown to block proliferation of immature erythroid progenitor cells. ${ }^{15}$ Interestingly DBA has been associated with mutations now in a number of different ribosomal protein genes including RPS19, RPS24, RPS17, RPL35A, RPL5, RPL11, and RPS7 in approximately $43 \%$ of patients. ${ }^{16} \mathrm{Im}$ portantly, an acquired internal deletion on chromosome $5 \mathrm{q}$ involving the CDR of the $5 \mathrm{q}$ syndrome (and loss of RPS14) has been recently described in a patient with non-classical DBA. 17

The anaemia in DBA and the $5 \mathrm{q}$ - syndrome is due to a failure of erythropoiesis and intriguingly both disorders show haploinsufficiency for ribosomal proteins, RPS19 and RPS14 respectively, required for the maturation of $40 \mathrm{~S}$ ribosomal subunits. ${ }^{13,18}$ Mutations in RPS19 impair pre-rRNA processing of the $18 \mathrm{~S}$ rRNA, which leads to decreased production of the 40S ribosomal subunit ${ }^{19}$ and RPS14 haploinsufficiency causes a similar outcome, ${ }^{11}$ thus linking the pathogenesis of the $5 q$ - syndrome to 
DBA. Moreover, similarities in the defective gene expression patterns observed in the CD34+ cells of patients with DBA and patients with the $5 q$ - syndrome were recently reported by Pellagatti et al., including the down-regulation of multiple ribosomal genes and genes involved in translation initiation and the up-regulation of several proapoptotic genes, further suggesting that the $5 \mathrm{q}$ - syndrome represents a disorder of aberrant ribosome biogenesis. ${ }^{20}$ These abnormalities may lead to impairment of ribosome biogenesis and subsequent reduction of protein translation capacity, a defect which may be of particular importance for developing erythroid cells, whose survival and division require large amounts of protein synthesis.

A number of other bone marrow failure syndromes are caused by defects in genes known to play a role in ribosome biogensis including Shwachman-Diamond Syndrome, ${ }^{21}$ Dyskeratosis Congenita, Cartilage Hair Hypoplasia, and the demonstration of RPS14 as a 5q- syndrome gene further suggests that defective ribosomal biogenesis may have a more general relevance in leukaemogenesis. ${ }^{22}$

\section{P53 activation underlies the anemia in the $5 q$ - syndrome}

P53, a key regulator of cell growth and cell death, is maintained at a low level during normal cell growth and is activated in response to various cellular stresses. Impaired ribosomal biogenesis, such as that resulting from haploinsufficiency of certain ribosomal proteins can cause nucleolar stress.23,24 Signal mediator proteins then activate p53 by inhibiting ubiquitylation (and degradation) by MDM2, the major regulator of p53.25 Activated p53 then promotes the transcription of its many target genes resulting in p53-dependent cell cycle arrest or apoptosis. It is now widely recognised that p53 activation is a common response to deficiency of ribosomal proteins in various diseases including DBA and Treacher Collins syndrome. ${ }^{24,26}$

We have recently generated a mouse model of the $5 \mathrm{q}$ - syndrome using large-scale chromosomal engineering. ${ }^{27}$ Haploinsufficiency of the Cd74-Nid67 interval caused macrocytic anemia, prominent erythroid dysplasia and monolobulated megakaryocytes in the bone marrow. The Cd74-Nid67 interval on mouse chromosome 18 is syntenic with a region within the CDR of the human $5 \mathrm{q}$ - syndrome ${ }^{7}$ and contains 8 known genes of which 2 have been excluded (Ndstl and Cd74) leaving Rps14, Synpo, Myoz3, Dctn-4, Rbm22 and Nid67 as candidates. ${ }^{27}$ It is most probable that RPS14 is the major gene in relation to the phenotype. The ' $5 \mathrm{q}$ - mouse' has a defective bone marrow progenitor development and bone marrow cells expressing high amounts of p53 with increased apoptosis. The $5 q$ - mouse was crossed with p53 deficient mice and significantly this rescued the progenitor cell defect, restoring hematopoietic stem cell bone marrow populations. ${ }^{27}$ These data suggest that a p53-dependent mechanism underlies the pathophysiology of the 5q- syndrome.

We have recently shown that induction of p53 and up-regulation of the p53 pathway occurs in the human $5 q-$ syndrome $^{28}$ and Dutt $e t$ $a l$. have demonstrated that haploinsufficiency of RPS14 indeed causes activation of p53 in human erythroid cells. ${ }^{29}$

\section{Cooperating events in the development of the $5 q$ - syndrome}

There is compelling data suggesting that haploinsufficency of RPS14 gene causes the erythroid differentiation defect of the $5 \mathrm{q}$ - syndrome ${ }^{11,27}$ and there is evidence suggesting that loss of the miRNA genes miR-145 and miR-146a (mapping within and adjacent to the CDR of the $5 q$ - syndrome, respectively) may play a role in the abnormalities of the megakaryocyte lineage observed. ${ }^{30}$ Thus several cooperating genetic events may be necessary in the development of the $5 \mathrm{q}$ - syndrome. ${ }^{31}$ Whether RPS14 or these microRNA genes are causal genes in relation to producing a clonal haematopoietic disorder, and whether haploinsufficiency of an additional gene or genes is involved are important questions remaining to be answered. Haploinsufficiency of other genes localised within the CDR such as the tumour suppressor gene $S P A R C$, or indeed mutations in genes mapping elsewhere in the genome, could play a role in establishing clonal dominance. ${ }^{32}$ Clearly further mouse knockout models and whole genome sequencing studies might prove very informative in relation to all these questions.

\section{References}

1. Van den Berghe H, Cassiman JJ, David G, et al. Distinct haematological disorder with deletion of long arm of no. 5 chromosome. Nature 1974;251:437-8.

2. Boultwood J, Lewis S, Wainscoat JS. The 5q-syndrome. Blood 1994;84:3253-60.

3. Giagounidis AA, Germing U, Wainscoat JS, et al. The 5q- syndrome. Hematology 2004; 9:271-7.

4. Vardiman JW, Harris NL, Brunning RD. The World Health Organization (WHO) classification of the myeloid neoplasms. Blood 2002;100:2292-302.

5. Jaju RJ, Boultwood J, Oliver FJ, et al. Molecular cytogenetic delineation of the critical deleted region in the $5 \mathrm{q}$ - syndrome. Genes Chromosomes Cancer 1998;22: 251-6.

6. Boultwood J, Fidler C, Lewis S, et al. Molecular mapping of uncharacteristically small $5 q$ deletions in two patients with the 5q- syndrome: delineation of the critical region on $5 \mathrm{q}$ and identification of a $5 \mathrm{q}$ breakpoint. Genomics 1994;19:425-32.

7. Boultwood J, Fidler C, Strickson AJ, et al. Narrowing and genomic annotation of the commonly deleted region of the $5 \mathrm{q}$ - syndrome. Blood 2002;99:4638-41.

8. Boultwood J, Pellagatti A, Cattan $\mathrm{H}$, et al. Gene expression profiling of CD34+ cells in patients with the $5 \mathrm{q}$ - syndrome. $\mathrm{Br} \mathrm{J}$ Haematol 2007;139:578-89.

9. Knudson A. Alfred Knudson and his twohit hypothesis. (Interview by Ezzie Hutchinson). Lancet Oncol 2001;2:642-5.

10. Largaespada DA. Haploinsufficiency for tumor suppression: the hazards of being single and living a long time. J Exp Med 2001;193:F15-8.

11. Ebert BL, Pretz J, Bosco J, et al. Identification of RPS14 as a 5q- syndrome gene by RNA interference screen. Nature 2008; 451:335-9.

12. Lipton JM, Atsidaftos E, Zyskind I, Vlachos A. Improving clinical care and elucidating the pathophysiology of Diamond Blackfan anemia: an update from the Diamond Blackfan Anemia Registry. Pediatr Blood Cancer 2006;46:558-64.

13. Flygare J, Karlsson S. Diamond-Blackfan anemia: erythropoiesis lost in translation. Blood 2007;109:3152-4.

14. Draptchinskaia N, Gustavsson P, Andersson $\mathrm{B}$, et al. The gene encoding ribosomal protein $\mathrm{S} 19$ is mutated in DiamondBlackfan anaemia. Nat Genet 1999;21: 169-75.

15. Ebert BL, Lee MM, Pretz JL, et al. An RNA interference model of RPS19 deficiency in Diamond-Blackfan anemia recapitulates defective hematopoiesis and rescue by dexamethasone: identification of dexamethasone-responsive genes by microarray. Blood 2005;105:4620-6.

16. Doherty L, Sheen MR, Vlachos A, et al. Ribosomal protein genes RPS10 and RPS26 are commonly mutated in DiamondBlackfan anemia. Am J Hum Genet 2010; 86:222-8.

17. Vlachos A, Farrar J, Atsidaftos E, et al. 5qMyelodysplastic Syndrome, In One of 23 Children Lacking a Known Ribosomal Gene Mutation, Masquerading as Diamond Blackfan Anemia (DBA) and Responding to Lenalidomide. 52nd American Society of Hematology Meeting and Exposition. 2010;Abstract LBA-52.

18. Moritz M, Paulovich AG, Tsay YF, Woolford JL, Jr. Depletion of yeast ribosomal proteins L16 or rp59 disrupts ribosome assembly. J Cell Biol 1990;111:2261-74.

19. Flygare J, Aspesi A, Bailey JC, et al. Human RPS19, the gene mutated in DiamondBlackfan anemia, encodes a ribosomal protein required for the maturation of $40 \mathrm{~S}$ 
ribosomal subunits. Blood 2007;109:980-6.

20. Pellagatti A, Hellstrom-Lindberg E, Giagounidis A, et al. Haploinsufficiency of RPS14 in 5q- syndrome is associated with deregulation of ribosomal- and translationrelated genes. Br J Haematol 2008;142:57-64.

21. Menne TF, Goyenechea B, Sanchez-Puig N, et al. The Shwachman-Bodian-Diamond syndrome protein mediates translational activation of ribosomes in yeast. Nat Genet 2007;39:486-95.

22. Narla A, Ebert BL. Ribosomopathies: human disorders of ribosome dysfunction. Blood 2010;115:3196-205.

23. Panic L, Montagne J, Cokaric M, Volarevic S. S6-haploinsufficiency activates the p53 tumor suppressor. Cell Cycle 2007;6:20-4.

24. McGowan KA, Li JZ, Park CY, et al. Ribosomal mutations cause p53-mediated dark skin and pleiotropic effects. Nat Genet 2008;40:963-70.

25. Fang S, Jensen JP, Ludwig RL, et al. Mdm2 is a RING finger-dependent ubiquitin protein ligase for itself and p53. J Biol Chem 2000;275:8945-51.

26. Jones NC, Lynn ML, Gaudenz K, et al. Prevention of the neurocristopathy Treacher Collins syndrome through inhibition of p53 function. Nat Med 2008;14:125-33.

27. Barlow JL, Drynan LF, Hewett DR, et al. A p53dependent mechanism underlies macrocytic anemia in a mouse model of human $5 q$ - syndrome. Nat Med 2010;16:59-66.

28. Pellagatti A, Marafioti T, Paterson JC, et al. Induction of p53 and up-regulation of the p53 pathway in the human $5 q$ - syndrome. Blood 2010;115:2721-3.

29. Dutt S, Narla A, Lin K, et al. Haploinsuffi- ciency for ribosomal protein genes causes selective activation of p53 in human eryxthroid progenitor cells. Blood 2011;117: 2567-76.

30. Starczynowski DT, Kuchenbauer F, Argiropoulos $\mathrm{B}$, et al. Identification of miR145 and miR-146a as mediators of the $5 \mathrm{q}$ syndrome phenotype. Nat Med 2010;16: 49-58.

31. Boultwood J, Pellagatti A, McKenzie AN, Wainscoat JS. Advances in the 5q- syndrome. Blood 2010;116:5803-11.

32. Pellagatti A, Jadersten M, Forsblom AM, et al. Lenalidomide inhibits the malignant clone and up-regulates the SPARC gene mapping to the commonly deleted region in 5q- syndrome patients. Proc Natl Acad Sci U S A 2007;104:11406-11. 